\title{
HOMOSEXUALITA A STARÉ UMĚNÍ: POZNÁMKY K INTERPRETACI MUŽSKÝCH RENESANČNÍCH PORTRÉTŮ
}

\author{
LIUBOV MARSOVA \\ Ústav pro dějiny umění, Filozofická fakulta Univerzity Karlovy \\ E-mail: marsovaliubov@gmail.com
}

\begin{abstract}
Homosexuality and Old Art: Notes to Interpretation of Male Portraits of Renaissance The paper is concerned with the problematic of one of the aspects of the perception of the male portrait of the Renaissance. The article is a separate chapter of the master's thesis devoted to the male portrait of friends in Italian Renaissance painting. The contemporary (current) viewer can perceive old masters portraits rather ambiguously, including as images of homosexuals. However, for such statements is necessary to realize very confidently what exactly "homosexuality" means and whether such a concept existed in the past. In addition, it is necessary to have as much knowledge as possible about the most varied aspects of the period under study, while always be aware that our knowledge is very mediocre and limited. The author critically analyzes the studies, in which the problem of the representation of homosexuality in old art is touched upon, and tries to identify methodological warnings for further interpretations. In conclusion, the author proposes new open discourses for future research in this field, encourages researchers to take a fresh look at not only the portraits of the Renaissance, but also at their own interpretations.

Keywords: Portraits; Renaissance; homosexuality; Italy; art history; paintings; sexuality; Foucault; Giorgione; Pontormo; Titian; Raphael; Renaissance poetry; interpretation
\end{abstract}

Homosexualita stále zůstává jedním $\mathrm{z}$ relativně málo probádaných témat $\mathrm{v}$ dějinách umění; minimálně kvưli tomu, že byla v širším společenském kontextu „objevena“ relativně nedávno a například $\mathrm{v}$ americkém prostředí si zatím udržuje charakter „boje za práva gayư“. V současnosti často vznikají publikace, které získávají popularitu převážně díky svým provokativním názvům a které jsou postaveny zejména na spekulacích o „kvantitě“ (např́íklad různé historické „seznamy“), nebo „kvalitě“ jednotlivců (významné osobnosti), čímž nepřesahují úroveň žlutého tisku. Ve své knize Homosexualita v dějinách české kultury Martin Putna označuje podobné spisy názvem „apologický biografismus". ${ }^{1}$

Výše zmíněná literatura spíše odvrací zájem odborníků od zkoumání této oblasti a v určité míře znevažuje ty seriózní odborné studie, které odvážně vznikají. Prakticky v každém př́padě nesou úvahy o vztazích starého umění a homosexuality charakter kritiky dosavadního bádání a uměleckohistorické sebereflexe. Nicméně odborníci by se neměli vzdávat podobných pokusů a předávat tento diskurs do rukou bulvárních autorů.

Před začátkem pojednání o homosexualitě v renesančním umění je nutné položit několik důležitých otázek, odpovědi pak určují celkový charakter výzkumu. Základní otáz-

1 Martin C. Putna et al., Homosexualita v dějinách české kultury, Praha 2013, s. 24. 
ka zní: co je homosexualita? Je nutné na to odpovědět aspoň v rámci jednoho konkrétního bádání. Nejde o to, co znamená homosexualita po medicínské a biologické stránce, ale o to, co se vnímá jako homosexualita při uvažování o uměleckém díle a co tak bylo vnímáno šest staletí před tím. Přestože na poslední otázku nelze odpovědět přesně, je onu neviditelnou linii zapotřebí určit.

Pokud budeme přistupovat k otázce homosexuality z dnešního pohledu, je nutné začít zvláštní diskursem, jenž je ovšem těžko slučitelný s diskursem historickým. Stejná gesta, stejné pohledy, oblečení a jiné věci, které jsou dnes považovány za „symboly“ homosexuality, nemusely být vnímané stejně člověkem minulosti. Jednalo by se spíš o výzkum vnímání (termín z literární vědy - tzv. receptivní estetiky). Uvažování o obrazu přestává být spojeno s dějinami vůbec, ale má vztah jenom k jednomu konkrétnímu uměleckému dílu v mimočasovém rozměru.

V prrípadě „historického“ diskursu je nutné aspoň přibližně pochopit, o čem se konkrétně jedná, když mluvíme o „homosexualitě v umění 16. stoleti““ a jaké existují podklady pro zkoumání. Jak v „soudobém“ „vizuálním“ diskursu, tak i v diskursu „historickém“ se nelze vyhnout otázce - o či homosexualitu se vlastně jedná?

Klíčovým momentem pro pochopení homosexuality je vědomí toho, že homosexualita jako taková ve starší době vlastně vůbec neexistovala. To, co se pod tímto pojmem myslí dnes, je produktem kulturních dějin od 18. století. Michel Foucault poukazuje na to, že sexuální vztahy byly do té doby řízeny v rámci stejného systému (ze strany církve, občanského práva apod.) jako ostatní složky společenského života - stejný přístup jako kupř́ikladu ke krádeži či pomluvě byl aplikován také na hříchy typu manželská nevěry, incest a také „sodomie“. Pojetí „nepřirozenosti“, „úchylky“, které se začalo používat v odsuzující rétorice následujících staletí, tehdy neexistovalo, jak manželská nevěra, tak sodomie byly vnímány jako přestupek porušující zákon. ${ }^{2}$ Termín „sodomie“, kterým operovaly někdejší předpisy, přitom není přesně definován. Jednalo se ovšem v každém př́padě jednoznačně pouze o konkrétní fyzický čin - důraz na sny, touhy, duševní vnitřní procesy začal být kladen teprve po protireformačním období. Pro období renesance proto není snadné najít pro tuto oblast lidských vztahů správný termín. Zatímco „homosexualita“ jako pojem neexistovala, termín „sodomie“ do sebe zase nemůže zahrnout oblast vnitřních pocitů, myšlenek, platonické lásky, tedy právě to, co se vyhledává na portrétech ve starém umění.

Pojetí homosexuality nepochybně odráželo dělení uvnitř určité společnosti (církev, aristokracie, buržoazie, rolnictvo), přičemž toto dělení není jediné možné (jiným je literatura, hudba, církevní předpisy, občanské zákony). Hřích sodomie byl dlouhou dobu přísně pronásledován církví a zakazován nařízeními vládnoucích autorit. Právě tyto zákazy a dokumentace pronásledování přitom dnes slouží jako hlavní podklad pro bádání v této oblasti. Např́iklad je známo, že tresty za „sodomii“ ze strany církve nebyly stejně kruté pro aristokracii jako pro rolnictvo. ${ }^{3}$

Pokud je řeč o homosexualitě autora uměleckého díla, je nejprve nutné zaujmout nějaké stanovisko vůči otázce vztahu osobnosti „autora“ a jeho díla. V celé řadě badatelských prací 19. století byla postava „génia“ podstatná, k ní jako k centru se vztahovaly veškeré

2 Michel Foucault, Volja $k$ istině: po tu storonu znanija, vlasti i seksualnosti, Moskva 1996, s. 97-133. České vydání: Michel Foucault, Dějiny sexuality. I, Vưle k vědění, Praha 1999.

3 Guy Poirier, L’homosexualité dans l'imaginaire de la Renaissance, Paris 1996, s. 8-21. 
nitky interpretace. První generace badatelů, kteří začali analyzovat homosexualitu v umění jako historický fenomén, přitom náleží právě k poslední čtvrtině 19. století. Stojí za zmínku naprŕklad práce britského kritika a básníka Johna Addingtona Symonda (1840-1893). Ve svých knihách Life of Michelangelo, Life of Benvenuto Cellini, The Renaissance in Italy se poprvé pokusil překonat cenzuru a nepozornost starších badatelů, pokoušel se propojit osobní život umělců s jejich díly. ${ }^{4}$ Tato generace badatelů však nebyla schopna překonat určitá omezení své doby, jak metodologická, tak i filozofická. Často připisovali homosexualitu historickým osobnostem na základě kritérií, která nemohou sloužit jako doklady: psychické zvláštnosti, netypické chování, odívání apod. Kromě toho si Symonds byl vědom své vlastní homosexuality a rozhodl se doplnit život Celliniho „nejtemnějšími chtíči, které deformovaly florentskou společnost své doby“. 5

Další důležitou kapitolu tvořil také odkaz Sigmunda Freuda s jeho interpretací vzpomínky na dětství Leonarda da Vinciho. Ve své studii Vzpomínka z dětství Leonarda da Vinciho na základě dochovaných textů renesančního mistra dospívá k závěru, že umělec byl v důsledku nepřekonaného oidipovského komplexu založen homosexuálně, ale svou homosexualitu sublimoval do své tvorby a do platonických vztahů ke svým žákům. ${ }^{6}$ Freudova práce se stala velice inspirativní, nebot nabízela novou cestu interpretaci uměleckých děl, avšak později byl tento psychoanalytický př́stup přehodnocen.

Ovšem po zrušení autora jakožto „centra“ umění Barthesem, ${ }^{7}$ Foucaultem ${ }^{8}$ a do jisté míry i psychoanalýzou Lacana ${ }^{9}$ se zdá mluvit o "géniovi“ jakožto o základní postavě dějin umění skoro nevhodné, i když se nelze často obejít bez jeho konstrukce. Pochopení toho, zda pro určité bádání bude použito pojetí „autora“, je každopádně velice důležité, nebot’ se od toho odvíjí, jak bude vnímáno umělecké dílo. I kdyby nějaký umělec byl gay, nemuselo se to nutně projevovat v jeho umělecké tvorbě. Na druhou stranu to, že gayem nebyl, ještě neznamená, že téma nezobrazoval. Vztah autora k homosexualitě mohl být jakýkoliv, ale to, jak dílo žije v očích diváka, je úplně jiný příběh.

Dále pokud se mluví o homosexuálním modelu na nějakém portrétu, vzniká řada jiných problémů. Je-li zobrazená osobnost zároveň objednavatelem? Musí se něco z osobního života odrážet na barevné ploše? Dostáváme se do virtuální oblasti vztahů mezi umělcem a jeho modelem a mluvíme o tom, jak umělec vnímal model a jak model/ objednavatel chtěl být prezentován.

Jaký byl objednavatel? Byla to stejná postava na portrétu a zároveň homosexuál, nebo homosexuál, který chtěl mít portrét nějakého člověka? Věčná otázka, která je vždy spojena s díly starých mistrů - kde je hranice mezi přáním objednavatele a úmyslem samotného autora?

4 James M. Saslow, Ganymede in the Renaissance: Homosexuality in art and society, New Haven - London 1986. s. 14. - Nebo Whitney Davis, Queer beauty: Sexuality and aesthetics from Winckelmann to Freud and beyond, New York 2010, s. 99-134.

5 Ibidem.

6 Sigmund Freud, Vzpomínka z dětství Leonarda da Vinci [Eine Kindheitserinnerung des Leonardo da Vinci (1910)], Praha 1991. - Putna (pozn. 1), s. 23.

Roland Barthes, Smrt autora, Aluze X, 2006, č. 3, s. 75-77.

Michel Foucault, „Qu'est-ce qu'un auteur?“(1969), Paris 1994.

Např́klad Jacques Lacan, Séminaire Les quatre concepts fondamentaux de la psychanalyse. Les fondements de la psychanalyse, Paris 1964. Autorka měla k dispozici ruské vydání: Jacques Lacan, Seminary, kniga XI (1964), Četyre osnovnyje ponjatija psychoanaliza, Moskva 2004. s. 116-130. 
Konečně existuje ještě další „tvưrce“, který je pro nás nejbližší a zároveň nejvzdálenější - divák. Tuto „masku“ může použít každý z aktérů: umělec, který není vyloučen ze společnosti a reflektuje svou kulturu, ve které žije; objednavatel, který mohl bud' dát umělci konkrétní zásady, anebo ho nechat tvořit samostatně; jsou to měštané v Rímě, Benátkách a Florencii, návštěvníci a přátelé; konečně to jsme i my, vytvářející tuto konstrukci vnímání, náš vztah k homosexualitě je stejně důležitý a musí být zahrnut do diskursu. Opatrné formulace typu „nejednoznačná sexualita“ tento problém neřeší: taková „nejednoznačnost“" se v podstatě rodí v očích diváka, nikoliv v barevné vrstvě. ${ }^{10}$

Ze všeho řečeného vyplývá, že homosexuální diskurs ve vztahu k dílům starého umění je velice složitým problémem a vyvolává víc otázek než odpovědí.

\section{Přehled dosavadního bádání}

Tématu homosexuality v renesančním umění byla v poslední době věnovaná aktivní pozornost badatelů, jejichž publikace se ovšem nedokázaly vyhnout některým problémům v př́istupu, které byly probrány výše. Na tomto místě je nutné připomenout několik jmen, jejichž práce jsou s výzkumem homosexuality spojeny nejúžeji. Přestože například Guy Poirier se zajímá spíš o renesanci ve francouzském prostředí, metodologické postřehy, které přináší v úvodu své knihy, jsou velice cenné. ${ }^{11}$ Patricia Simons se dlouhou dobu zabývá otázkou reprezentace homosexuality a „mužskosti“ v renesančním umění, zasahuje rovněž i do feministického diskursu tím, že zkoumá problematiku ženského portrétu. ${ }^{12}$ Publikace Armandea Maggiho, primárně profesora literatury a dějin středověké italské kultury, jsou prrínosné i pro renesanční umění, a to v tom smyslu, že dává představu o tom, jak byla otázka homosexuality reflektována ve spisech Marsilia Ficina a následující generace. ${ }^{13}$ Ulrich Pfisterer se zabývá tím, zda homosexuální vztahy mohly mít vliv na výtvarné umění: postupuje většinou skrze zkoumání literárních pramenů, dopisů a archivních dokumentů. Dá se říct, že jeho zájem o tuto problematiku se začal rozvíjet po jeho „objevu“ homosexuálního kontextu v díle římského medailéra Lyssipa. ${ }^{14}$ Christofer Reed rozbíjí rámec evropocentrismu tím, že zkoumá homosexualitu v umění z celosvětového hlediska, včetně zaoceánských kmenů a starobylých kultur. Snaží se porovnat rozmanitá pojetí homosexuality v různém prostředí a rozdílné vztahy mezi homo-

10 Patricia Simons, Homosociality and erotics in Italian Renaissance portraiture, in: Joanna Woodall (ed.) Portraiture, Manchester 1997, s. 29-51.

11 Viz Poirier (pozn. 3). V úvodu pod názvem Imaginaire et homosexualité? (Imaginárnost a homosexualita?) dává přehled literatury jak historického charakteru, tak i autorů, kteří se zabývali spíše psychoanalýzou.

12 Patricia Simons, Women in frames: The gaze, the eye, the profile in Renaissance portraiture, in: Norma Broude - Mary D. Garrard (edd.), The expanding discourse, Boulder 1992, s. 38-57. - eadem, Homosociality and erotics in Italian Renaissance portraiture, in: Joanna Woodall (ed.) Portraiture, Manchester 1997, s. 29-51.

13 Armando Maggi, On Kissing and Sighing, in: Beert C. Verstraete - Vernon Provencal (edd.), Same-sex desire and love in Greco-Roman antiquity and in the classical tradition of the, Journal of Homosexuality XLIX, 2005, č. 3-4, s. 315-339.

14 Ulrich Pfisterer, Lysippus und seine Freunde: Liebesgaben und Gedächtnis im Rom der Renaissance, oder, Das erste Jahrhundert der Medaille, Berlin 2008. 
sexualitou a uměním. ${ }^{15}$ Marianne Koos a Jaynie Anderson zkoumají většinou benátské prostředí okruhu Giorgioneho. Jeho nejasné a mnohoznačné portréty se staly předmětem dlouhodobého zájmu těchto badatelek. ${ }^{16}$ Pod vedením Marianne Koosové rovněž vyšel sborník příspěvků věnovaných problematice homosexuality v umění. ${ }^{17}$ Bádání pokračuje nadále a nabízí stále více otázek než odpovědí. Především chybějí prameny, které by dokázaly jednoznačně určit význam některých mužských portrétů. A kromě toho tzv. „nejednoznačnost“ např́klad benátských mužských portrétů je výsledkem interpretace z pohledu současného diváka, a proto potřebuje velkou míru sebereflexe.

\section{Mužský renesanční portrét a homosexualita}

Nelze si nevšimnout, že ve většině případů portrétů anonymních žen v uměleckohistorické literatuře se objevuje výraz „ideál krásy“, který prý neměl nějaký reálný prototyp, tedy existující ženu. Ale v př́padě mužské reprezentace se nejčastěji jedná o „představu osobnosti“, člověka jako takového, jehož ctnosti a zásluhy jsou samozřejmě akcentovány. Nakolik taková představa o mužském portrétu odpovídá realitě?

Objednavatelem obrazů byl v převážné většině případů muž. Právě mužské publikum bylo adresátem výtvarného díla. Vyplývá z toho otázka, jestli mohl existovat také ideál krásy v mužském světě, který by nebyl ideálem vojenským, ideálem kondotiéra, dobyvatele, ale krásy zženštilejší, mladé a křehké jako na portrétech mladých pastýřo̊, Amorů, Erótů, Ganymedů, sv. Sebastianů. Pro čí oči byla vytvořena podobná plátna?

Pokud se ponoříme do dobové literatury - bud' filozofického charakteru, nebo krásné literatury - situace se komplikuje. Jak již bylo poznamenáno, slovo „sodomie“ v zákonech, předpisech a jiných dokumentech se vztahovalo jenom na fyzickou stránku vztahů, zatímco oblast duševních vztahů a touhy, vášní nebyla v době před protireformací ničemu podřízena. Velice nejednoznačně by se daly interpretovat pasáže Marsilia Ficina O lásce (jinak Komentář k Symposionu Platóna). Renesanční novoplatonik přímo tvrdí, že láska mezi muži je mnohem silnější a přirozenější než vztah se ženou. ${ }^{18}$ Přičemž je jasné, že Ficino nemá na mysli to, co se nazývalo „sodomií“, ale lásku platonickou, filozofickou, lásku jako ideální, všepohlcující přátelství. Je pravděpodobné, že by v dnešní době takové vztahy, ač nespojené s fyzickým vztahem, byly považovány za vztahy jednoznačně homosexuální. Ovšem v minulosti taková rozdělení neexistovala - znamená

15 Dokonce uvádí tabulku, ve které se snaží porovnat tyto rozdíly: Christopher Reed, Art and homosexuality: A history of ideas, New York - Oxford 2011, s. 8.

16 Jaynie Anderson, The Giorgionesque portrait II: Representations of homosociality, or the importance of friendship, in Renaissance Venice, in: Sylvia Ferino-Pagden (ed.), Giorgione entmythisiert, Turnhout 2008, s. 155-173. - Jeanette Kohl - Marianne Koos - Adrian W. B. Randolph (edd.), Renaissance love: Eros, passion, and friendship in Italian art around 1500, Berlin - München 2014.

17 Mechthild Fend - Marianne Koos (edd.), Mänlichkeit im Blick: Visuelle Inszenierungen in der Kunst seit der Frühen Neuzeit, Köln 2004.

18 Marsilio Ficino - Nina Revjakina (ed.), Kommentarij na Pir Platona, in: Vasilij Zubov (ed.) Istorija estetiky. Pamjatniki mirovoj estetičeskoj mysli. Moskva, 1962. - Český překlad se zatím připravuje: https://www.kosmas.cz/knihy/122240/o-lasce-de-amore, vyhledáno 28. 7. 2017. - Viz Maggi (pozn. 14), s. 317-321. 
to tedy, že objednavatelé portrétů tuto hranici nevnímali? ${ }^{19}$ Ideální přátelství a láska v pojetí novoplatonismu se prakticky nerozlišovaly: když si uvědomíme tento rozdíl, nebudou vznikat chybné interpretace uměleckých děl, například reliéfu se zobrazením dvou mužů $z$ dílny Pietra Lombarda. ${ }^{20}$ Přestože se mohlo jednat o zvláštní ilustraci Dialogu o lásce Marsilia Ficina, nelze považovat dílo za reprezentaci homosexuálních vztahů, jak je chápeme dnes. ${ }^{21}$

Renesanční novoplatonici také považovali mužskou krásu za nejdokonalejší, ale nejspíš skrze pozorování; domnívali se, že prostřednictvím půvabného vzhledu člověkem prostupuje půvabná duše a že osobnost, která má vnitřní hodnoty, bude mít i vnější krásu. Zobrazení, vizuální kontakt je pro renesanční novoplatoniky klíčový. Uznávání milovaného člověka, empatie, vcítění - tyto hodnoty jsou povýšeny do procesu skoro magického, božského rázu. Samotný vzhled a pohled z hlediska novoplatonismu 15. století nabývá neobyčejné síly. ${ }^{22}$

Jako jeden $\mathrm{z}$ př́ikladů složitosti terénu, do kterého zde vstupujeme, lze uvést traktát Flaminia Nobiliho Il Trattato dell'amore humano (Traktát o lidské lásce), ve kterém je představeno dost složité schéma druhů lásky a druhů polibků rozdělených na svaté, občanské, zamilované a chlípné. Přičemž pouze ten poslední se vztahuje výhradně na vztahy mezi mužem a ženou. ${ }^{23}$

Samozřejmě že uvažování novoplatoniků nebyla vždy přijata. Např́íklad Francesco Sansovino v Ragionamento d’amore zmiňuje, že společnosti novoplatoniků je třeba se vyhýbat, nebot jejich chování je dost pochybné. Tullia Aragonská v dopise Benedettu Varchimu velice ostře odsuzuje učení Marsilia Ficina. ${ }^{24}$

Nejvzdělanější osobnosti epochy jako Janus Pannonius, Pico della Mirandola, Galeotto Marzio da Narni a další byli s těmito myšlenkami, které se tehdy „objevovaly ve vzduchu“, obeznámeni. A pro dějiny zůstane navěky nejasné, zda např́klad Jana Pannonia s Galeottem spojoval jenom přátelský vztah v moderním pojetí. Ztracený Galeottův portrét, který namaloval Andrea Mantegna před rozloučením dvou přátel, je znám jenom podle veršů Jana Pannonia. Přestože verše se staly předmětem různých interpretací, nelze je považovat za doklad mileneckých vztahů. ${ }^{25}$ Stejně nelze říct nic konkrétního ani o vztazích portrétovaných na dochovaných dílech: mezi Raffaelem a jeho neznámým

19 Viz Foucault (pozn. 2). Ten označuje soudobou (20. století) společnost za „znovuobjevení viktoriánství“. Ve třech dílech nedokončeného velkého projektu Dějiny sexuality Foucault analyzuje, jak zákazy a „normy“ určovaly lidské chování po celé dějiny. Dnešní společnost také nazývá společností perverzí.

20 Viz Anderson (pozn. 17) s. 168.

21 Pietro Lombardo (dílna): Reliéf s profily starého a mladého muže, 1495-1500, mramor, Kunsthistorisches Museum, Vídeň. [Obr. 1]

22 Viz Ficino (pozn. 19). - Originální text Marsilio Ficino, Sopra Lo Amore ovvero Convito Di Platone, 1914: https://archive.org/details/MarsilioFicinoSopraLoAmoreovveroConvitoDiPlatoneCarabba Editore1914, vyhledáno 28. 7. 2017.

23 Viz Maggi (pozn. 14), s. 315-339.

24 Ibidem. Maggi cituje spis Dialogo dell'infinit à d’amore (Dialogy o nekonečnosti lásky) Tullie Aragonské. Tullia reaguje na otázku Varchiho o tom, jaký je její názor na milenecké vztahy mezi dvěma mládenci, nebot’ ve svém vztahu neusilují o pokračování rodu, a proto vyvstává otázka, zda jejich láska může být považována za „čistou“.

25 Ágnes Ritoók-Szalay, Andrea Mantegna e Giano Pannonio, in: Peter Farbaky - Louis A. Waldman (edd.) Italy \& Hungary, humanism and the art in the early Renaissance, Milano 2011, s. 151-172. Interpretace veršů viz také Liubov Marsova, Přátelské portréty v italském renesančním malírství (diplomová práce), Ústav pro dějiny umění FF UK v Praze, Praha 2017, s. 38-43. 
přítelem ${ }^{26}$ nebo mezi dvěma mladými muži na obrazu Jacopa Pontorma. ${ }^{27} \mathrm{I}$ když o fyzický vztah, př́sně zakázaný a odsuzovaný, se nejednalo, nelze jednoznačně odmítnout i to, že čistě platonické vztahy, tzv. ideální přátelství mohly mít i homosexuální náboj. Ještě jednou je třeba zdůraznit, že pojetí ideálního přátelství nevycházelo jenom ze spisů Cicerona De amicitia, k nimž odkazuje jeden z protagonistů Pontormova obrazu, když drží citát z nich, harmonicky se prolínalo s tehdejším novoplatonismem. Lze zmínit například spis Leona Battisty Alberti, který nese název $O$ rodině. Na základě spisů antických filozofů Alberti vynáší vztahy mezi dvěma muži na nejvyšší stupeň své hierarchie vztahů. ${ }^{28}$ Alberti nepochybně byl ovlivněn soudobým novoplatonským myšlením, které poznal na setkáních tzv. Platonské akademie v medicejské vile v Careggi.

Složitá situace vzniká v oblasti benátských portrétů. V Benátkách vzniká zvláštní žánr zobrazení většinou mladých „ideálü“ mužské zženštilé krásy v podobě děl na hranici alegorie a portrétu. Dokonce i obraz připisovaný dnes Giorgionemu v Palazzo Venezia v Ř́mě mohl být objednán jedním z podobných sběratelů kolekcí, které obsahovaly portréty mladých pastýřů, amorů apod., obeznámeného s novoplatonskými představami, čtoucího traktáty o lásce. ${ }^{29}$ Portrét mohl vystupovat jako plnohodnotný společník, kterému chybí jenom hlas. Vizuální ztělesnění ideálu mužské krásy mohlo být také i objektem lásky. Básně nalezené Ulrichem Pfistererem jsou věnovány portrétu krásného mladého „Daniela“, do kterého se autor veršů zamiloval natolik, že hodlá skončit svůj život sebevraždou. Lhostejnost obrazu, jeho chladnost a nepřístupnost hubí básníka, jako odraz sebe samého ve vodní hladině hubí mladého Narcise:

\section{Na dospívajícího Daniela v rozpuku}

Ó pevná naději, která mi září, obraze Daniela, zř́telnice mých očí už po dlouhý čas.

Jsem spalován láskou $k$ tobě a střelu nosím v hrudi raněn, a ty se nestaráš o naši (= mou) bolest. Před tvou tvárí probodnu mečem svou hrud' a vypustím duši se zuřivou bolestí. Na můj náhrobek budou napsány takové zpěvy: Tady leží. Pohledte, mládenci, na toho, jehož onen proradný spanilý Daniel krutou smrtí zahubil. Říká se o tobě, že jsi svědek i pưvodce mé smrti. ${ }^{30}$

26 Raffaello Santi: Autoportrét s př́telem, 1518-1520, olej na plátně, $99 \times 83 \mathrm{~cm}$, Louvre, Paříž. [Obr. 2]

27 Jacopo Carucci, zv. Pontormo: Portrét dvou přátel, kol. 1523-1524, olej na dřevě, $88 \times 68 \mathrm{~cm}$, Galleria di Palazzo Cini, Fondazione Cini, Benátky. [Obr. 3]

28 Leon Battista Alberti, Knigi o semje, Moskva, 2008, s. 242-318.

29 Giorgione da Castelfranco (přip.): Portrét mladíka s bigarádií v ruce a sluhou v pozadí, kol. 1502-1509, olej na plátně, 80 × 68 cm, Museo Nazionale del Palazzo Venezia, Řím. [Obr. 4]

30 [Překlad podle originálního textu]: ZODOMI IN DANIELEM ADOLESCENTVLVM PRIMARIVM // 0 Spes firma mihi fulgens Danielis ymago / Luminibus pupilla meis iam tempore longo / Vror amore tui telumque in pectore porto / Saucius \& nostri non est tibi cura doloris. / [...]/ Ante tuos vultuo [sie] gladio mea pectora dextra / Percutiam ejfundamque animam foribundo dolore. / Talia dehinc nostro scribentur carmina saxo: / Hic jacet aspicite, o Iuvenes, quem perfidus ille / Formosus daniel crudeli morte peremit, / Spectatosque mee mortis et diceris autor. Přepsáno z Ulrich Pfisterer, Freundschaftsbilder - Liebesbilder: Zum visuellen Code mänlicher Passionen in der Renaissance, in: Sibylle Appuhn-Radtke - Esther P. Wipfler (edd.), Freundschaft, München 2006, s. 239-259; s. 253, 
Dalším poukazem na vztah mužského portrétu a homosexuálního náboje může být portrét také zmíněný Pfistererem, pocházející od benátského malíre Francesca Torbida. ${ }^{31}$ Řádek z veršů zobrazený na plátně je citátem z poezie Girolama Angeriana, reflektující řecké antické básnictví věnované homosexuální lásce. Do stejné poetické linie patří rovněž verše vytvořené bratrem zmíněného Leonica Tomea, Bartolomea Fusca v Benátkách, věnované portrétu Giovanniho Belliniho. ${ }^{32}$

Interdisciplinární bádání, kterých by se zúčastnili historici umění, každodennosti, sexuality a filologové, se mohou stát pramenem pro nové výklady uměleckých děl. Propojení výtvarného umění a umění básnického je příznačné pro evropskou tradici od nejstarších časů. Pro italské renesanční umění lze uvést příklad florentského básníka zv. il Burchiello. Záhadné a složité sonety tohoto autora jsou předmětem sporů různých badatelů. ${ }^{33}$ Nicméně odvážím se vyslovit předpoklad, že výrazové prostředky nebo „kódy“ použité básníkem byly součástí dobové kultury a mohly být svým zpo̊sobem aplikovány rovněž ve výtvarném umění, například pro žánr portrétu. Zvlášt se to týká těch případů, kdy význam zobrazení nemusel být jasný pro každého, kdy se jednalo o portrét soukromého charakteru určeného pro intimní prostředí, jako jsou portréty blízkých přátel nebo milenců. Podobnou analýzou se zabýval např́klad již zmíněný historik umění John Shearman. Porovnával např́iklad básnické přístupy oslovení čtenáře a zapojení diváka do obrazu pomocí vizuálních nástrojů, jimiž je pohled portrétovaného, nebo gesta, se kterými se zobrazený obrátí na pozorovatele. ${ }^{34}$

\section{Závěr}

Jako objednavatel a divák uměleckého díla vystupoval převážně muž. Nelze jednoduše říct, z jakého důvodu si mohl objednávat zobrazení mladých mužů, která neměla reálný prototyp. Mohlo se jednat o nostalgii vlastního mládí, o abstraktní pozorování ideálu krásy a/nebo erotický podnět ( $v$ dnešním pojetí) nebo všechno dohromady - nelze to chápat jednoznačně. Pravděpodobné se jeví jedině to, že podobné portréty náležely k velice intimní oblasti lidského života a nebyly určeny pro širokou veřejnost.

Pojetí „ideálního přátelstvi“ harmonicky absorbovalo jak antické spisy, tak renesanční novoplatonskou filozofii. Nejpodstatnější je to, že pojetí lidských vztahů vůbec se výrazně lišilo od toho dnešního. Ideální přátelství zahrnovalo také i nefyzickou, platonickou

pozn. 1. Děkuji panu PhDr. Josefu Šimandlovi, Ph.D. za podstatnou pomoc při překládání latinského textu.

31 Francesco Torbido, Portrét mladíka s rưží, 1516, olej na plátně, $62 \times 51,8 \mathrm{~cm}$, Alte Pinakothek, Mnichov. [Obr. 5]

32 Jennifer Fletcher, Harpies, Venus and Giovanni Bellini's classical mirror: Some fifteenth century Venetian painters responses to the antique, in: Gustavo Traversari (ed.), Congresso Internazionale Venezia e l'Archeologia, Roma 1990, s. 170-176.

33 Poslední vydání sonetů s potvrzeným autorstvím: Domenico di Giovanni detto il Burchiello Antonio Lanza (ed.), Le poesie autentiche di Domenico di Giovanni detto il Burchiello, Roma, 2011. Interpretace sonetů viz: Alan K. Smith, Fraudomy: reading sexuality and politics in Burchiello, in: Jonathan Goldberg (ed.), Queering the Renaissance, Durham, 1994, s. 84-106. Antonio Corsaro, Appunti sullautoritratto comico fra Burchiello e Michelangelo, in: Aldo Galli - Chiara Piccinini Massimiliano Rossi (edd.), Il ritratto nell'Europa del Cinquecento, Firenze 2007, s. 117-136.

34 John K. G. Shearman, Only connect: Art and the spectator in the Italian Renaissance, Princeton 1992, s. $115-117$. 
lásku, která by mohla být z dnešního pohledu chápána jako homosexuální. Takzvaná „sodomie“, fyzický akt, byla pronásledována množstvím zákonů, zákazů, policií, církví, obecnou morálkou. Ale nefyzické vztahy v podstatě nebyly omezeny.

Je nutné podotknout, že žádné poznatky o intimních vztazích nemohou být základem definitivního výkladu uměleckého díla. Týká se to i př́padů, které jsou jaksi „potvrzené“ dokumenty ohledně některých umělců. Rozsáhlé pasáže, ve kterých Giorgio Vasari odsuzoval chování malíre Sodomy, ${ }^{35}$ nemohou sloužit jako klíč pro traktování jeho tvorby, stejně jako i případ Benvenuta Celliniho. ${ }^{36}$ Reč je především o rozšíření kontextu, o zapojení do naší představy o minulosti neviditelných „aktérü“, skrytých za oponu historických předsudků, cenzury, náboženských a občanských zákazů.

\section{LITERATURA A PRAMENY}

Leon Battista Alberti, Knigi o semje, Moskva 2008.

Jaynie Anderson, The Giorgionesque portrait II: Representations of homosociality, or the importance of friendship, in Renaissance Venice, in: Sylvia Ferino-Pagden (ed.), Giorgione entmythisiert, Turnhout 2008.

Roland Barthes, Smrt autora, Aluze X, 2006, č. 3.

Benvenuto Cellini, Žizň Benvenuto Cellini, Moskva, 1958.

Antonio Corsaro, Appunti sullautoritratto comico fra Burchiello e Michelangelo, in: Aldo Galli - Chiara Piccinini - Massimiliano Rossi (edd.) Il ritratto nell'Europa del Cinquecento, Firenze 2007.

Mechthild Fend - Marianne Koos (edd.), Mänlichkeit im Blick: Visuelle Inszenierungen in der Kunst seit der Frühen Neuzeit, Köln 2004.

Marsilio Ficino - Nina Revjakina (ed.), Kommentarij na Pir Platona, in: Vasilij Zubov (ed.) Istorija estetiky. Pamjatniki mirovoj estetičeskoj mysli. Moskva, 1962. - Český překlad se zatím připravuje: https:// www.kosmas.cz/knihy/122240/o-lasce-de-amore, vyhledáno 28. 7. 2017.

Marsilio Ficino, Sopra Lo Amore ovvero Convito Di Platone, 1914:

https://archive.org/details/MarsilioFicinoSopraLoAmoreovveroConvitoDiPlatoneCarabbaEditore1914, vyhledáno 28. 7. 2017.

Jennifer Fletcher, Harpies, Venus and Giovanni Bellini's classical mirror: Some fifteenth century Venetian painters responses to the antique, in: Gustavo Traversari (ed.), Congresso Internazionale Venezia e l'Archeologia, Roma 1990.

Michel Foucault, Volja $k$ istině: po tu storonu znanija, vlasti i seksualnosti, Moskva 1996. - České vydání: Michel Foucault, Dějiny sexuality I, Vưle k vědění, Praha 1999.

Michel Foucault, „Qu'est-ce qu'un auteur?“ (1969), Paris 1994.

Sigmund Freud, Vzpomínka z dètství Leonarda da Vinci [Eine Kindheitserinnerung des Leonardo da Vinci (1910)], Praha 1991.

Domenico di Giovanni detto il Burchiello - Antonio Lanza (ed.), Le poesie autentiche di Domenico di Giovanni detto il Burchiello, Roma 2011.

Jeanette Kohl - Marianne Koos - Adrian W. B. Randolph (edd.), Renaissance love: Eros, passion, and friendship in Italian art around 1500, Berlin - München 2014.

Jacques Lacan, Seminary, kniga XI (1964), Četyre osnovnyje ponjatija psychoanaliza, Moskva 2004.

Armando Maggi, On Kissing and Sighing, in: Beert C. Verstraete - Vernon Provencal (edd.), Same-sex desire and love in Greco-Roman antiquity and in the classical tradition of the, Journal of Homosexuality XLIX, 2005, č. 3-4.

Liubov Marsova, Prátelské portréty v italském renesančním malírství (diplomová práce), Ústav pro dějiny umění FF UK v Praze, Praha 2017.

35 Giorgio Vasari, Žizněopisanija naibolee znamenitych živopistcev, vajatelej i zodčich, polnoje izdanije v odnom tomé, Moskva 2008. s. 928-935.

36 Benvenuto Cellini, Žizñ Benvenuto Cellini, Moskva 1958, s. 537, pozn. 1 ke kap. XCIX. 
Ulrich Pfisterer, Lysippus und seine Freunde: Liebesgaben und Gedächtnis im Rom der Renaissance, oder, Das erste Jahrhundert der Medaille, Berlin 2008.

Guy Poirier, L'homosexualité dans l'imaginaire de la Renaissance, Paris 1996.

Martin C. Putna et al., Homosexualita v dějinách české kultury, Praha 2013.

Christopher Reed, Art and homosexuality: A history of ideas, New York - Oxford 2011.

Ágnes Ritoók-Szalay, Andrea Mantegna e Giano Pannonio, in: Peter Farbaky - Louis A. Waldman (edd.), Italy \& Hungary, humanism and the art in the early Renaissance, Milano 2011.

James M. Saslow, Ganymede in the Renaissance: Homosexuality in art and society, New Haven - London 1986. John K. G. Shearman, Only connect: Art and the spectator in the Italian Renaissance, Princeton 1992.

Patricia Simons, Women in frames: The gaze, the eye, the profile in Renaissance portraiture, in: Norma Broude - Mary D. Garrard (edd.), The expanding discourse, Boulder 1992. - eadem, Homosociality and erotics in Italian Renaissance portraiture, in: Joanna Woodall (ed.) Portraiture, Manchester 1997.

Alan K. Smith, Fraudomy: reading sexuality and politics in Burchiello, in: Jonathan Goldberg (ed.), Queering the Renaissance, Durham 1994.

Giorgio Vasari, Žizněopisanija naibolee znamenitych živopistcev, vajatelej i zodčich, polnoje izdanije $v$ odnom tomé, Moskva 2008.

Whitney Davis, Queer beauty: Sexuality and aesthetics from Winckelmann to Freud and beyond, New York 2010.

Joanna Woodall (ed.), Portraiture, Manchester 1997.

\section{HOMOSEXUALITY AND OLD ART: NOTES TO INTERPRETATION OF MALE PORTRAITS OF RENAISSANCE}

\section{Summary}

The paper is concerned with the problematic of one of the aspects of the perception of the male portrait of the Renaissance. The article is a separate chapter of the master's thesis devoted to the male portrait of friends in Italian Renaissance painting. The contemporary (current) viewer can perceive old masters portraits rather ambiguously, including as images of homosexuals. However, for such statements is necessary to realize very confidently what exactly "homosexuality" means and whether such a concept existed in the past. In addition, it is necessary to have as much knowledge as possible about the most varied aspects of the period under study, while always be aware that our knowledge is very mediocre and limited. The author critically analyzes the studies, in which the problem of the representation of homosexuality in old art is touched upon, and tries to identify methodological warnings for further interpretations. In conclusion, the author proposes new open discourses for future research in this field, encourages researchers to take a fresh look at not only the portraits of the Renaissance, but also at their own interpretations. 


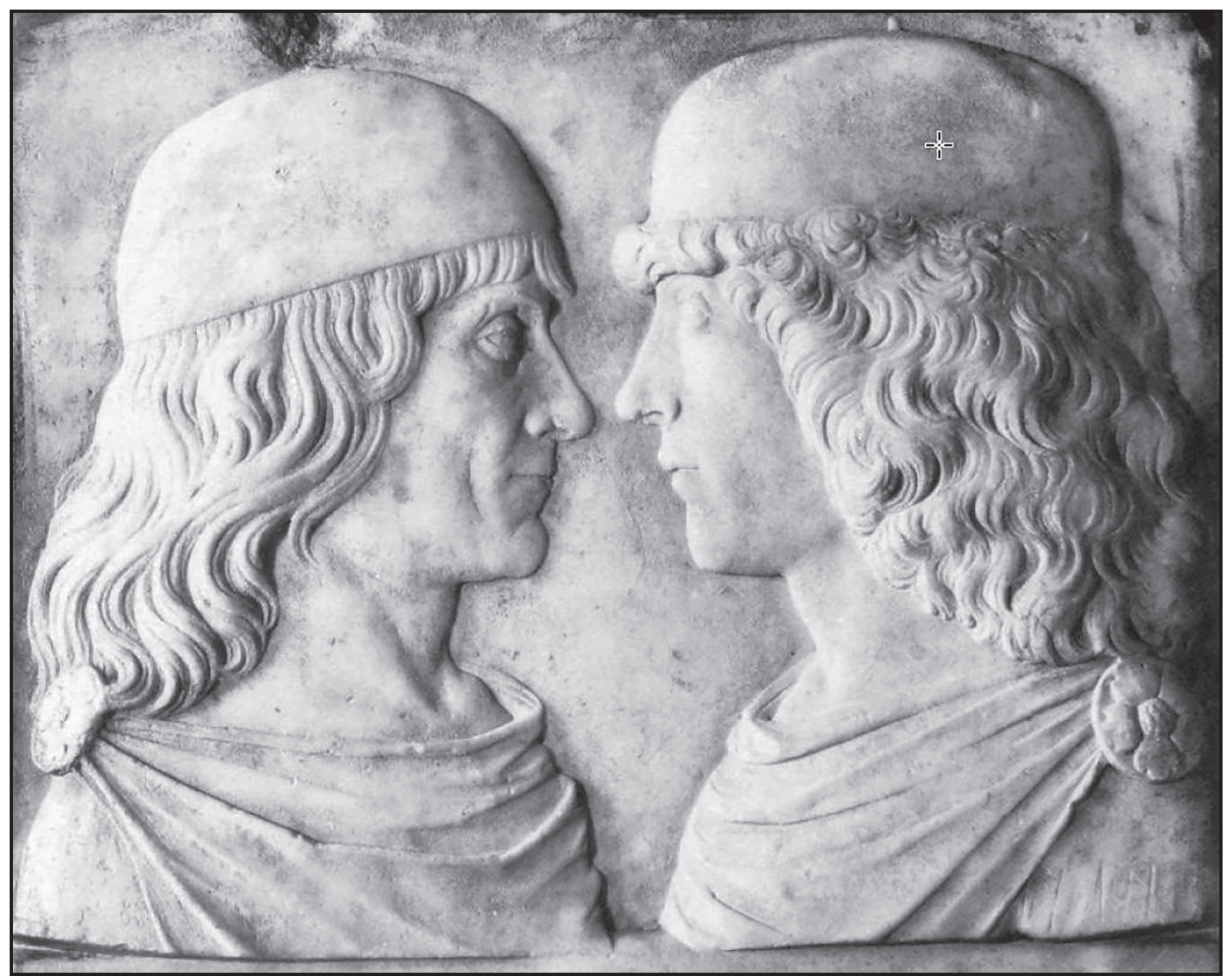

Obrázek 1: Pietro Lombardo (dílna): Reliéf s profily starého a mladého muže, 1495-1500, mramor, Kunsthistorisches Museum, Vídeň. Převzato z: Alison Luchs, Tullio Lombardo and ideal portrait sculpture in Renaissance Venice: 1490-1530, Cambridge 1995, s. 273, fig. 127

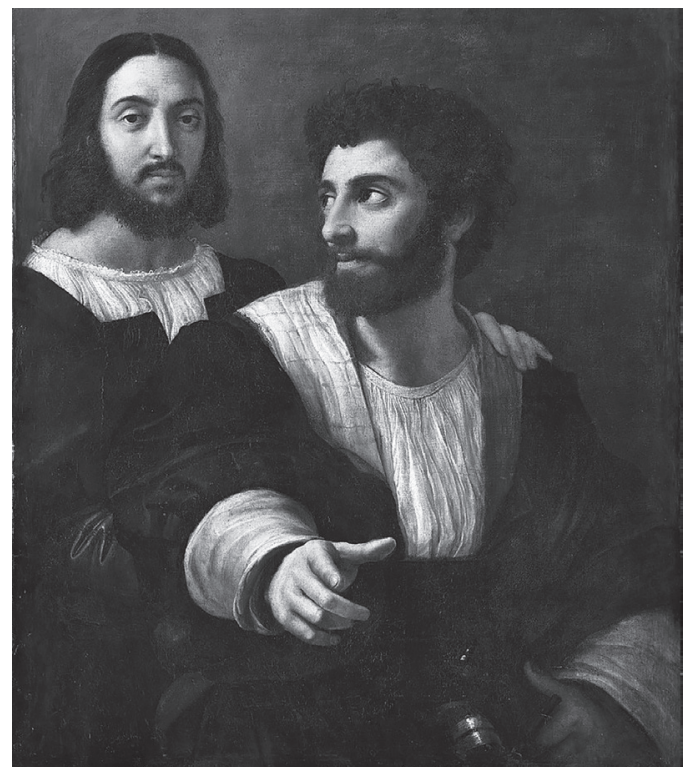

Obrázek 2: Raffaello Santi: Autoportrét $\mathrm{s}$ prŕtelem, 1518-1520, olej na plátně, $99 \times 83 \mathrm{~cm}$, Louvre, Paříž. Převzato z: Sylvie Béguin - Odile Menegaux, Les peintures de Raphael au Louvre, Paris 1984, s. 39 


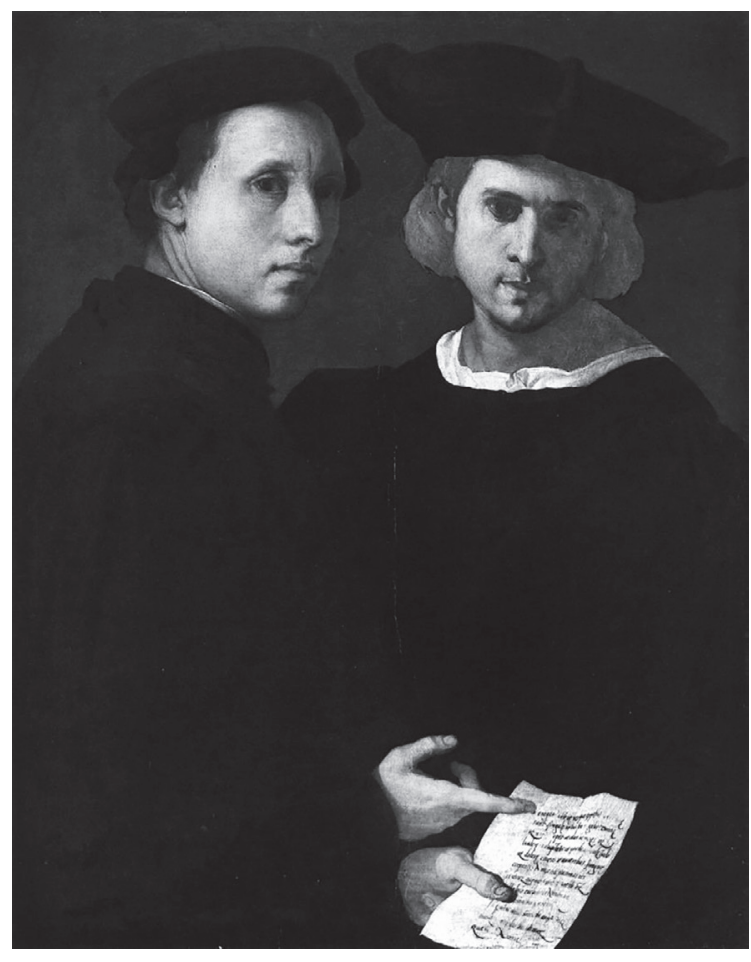

Obrázek 3: Jacopo Carucci, zv. Pontormo: Portrét dvou prátel, kol. 1523-1524, olej na dřevě, $88 \times 68 \mathrm{~cm}$, Galleria di Palazzo Cini, Fondazione Cini, Benátky. Převzato z: Alessandro Cecchi - Antonio Natali - Carlo Sisi (edd.), Lofficina della maniera: Varietà e fierezza nellarte fiorentina del Cinquecento fra le due repubbliche 1494-1530, Venezia, 1996, s. 296, kat. heslo 104

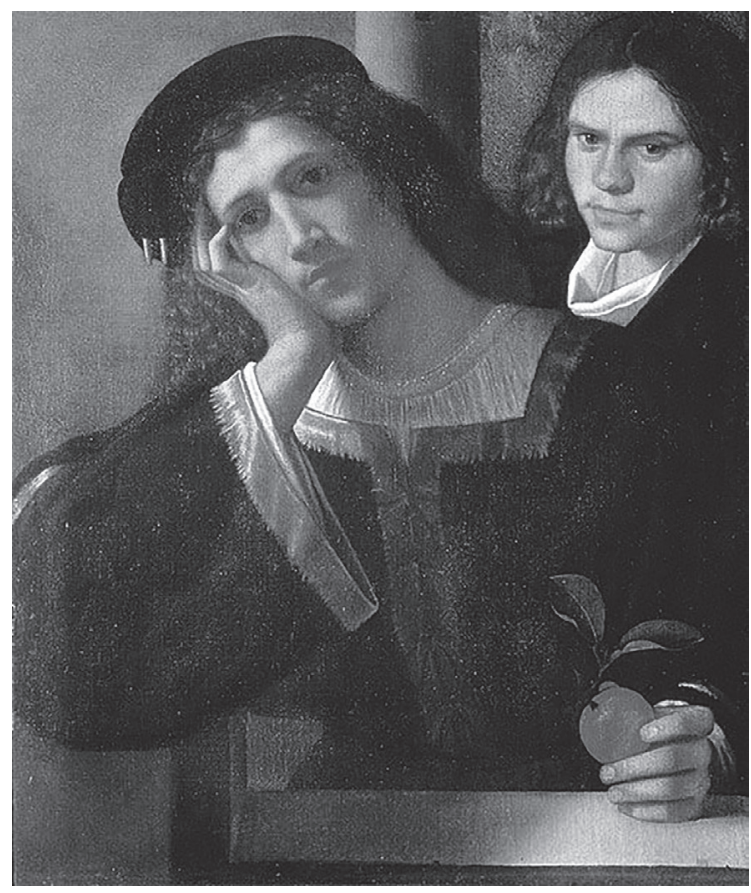

Obrázek 4: Giorgione da Castelfranco (přip.): Portrét mladíka s bigarádií $\mathrm{v}$ ruce a sluhou $\mathrm{v}$ pozadí, kol. $1502-1509$, olej na plátně, $80 \times 68 \mathrm{~cm}$, Museo Nazionale del Palazzo Venezia, Rím. Převzato z: Anderson (pozn. 17), s. 159 , fig. 4 


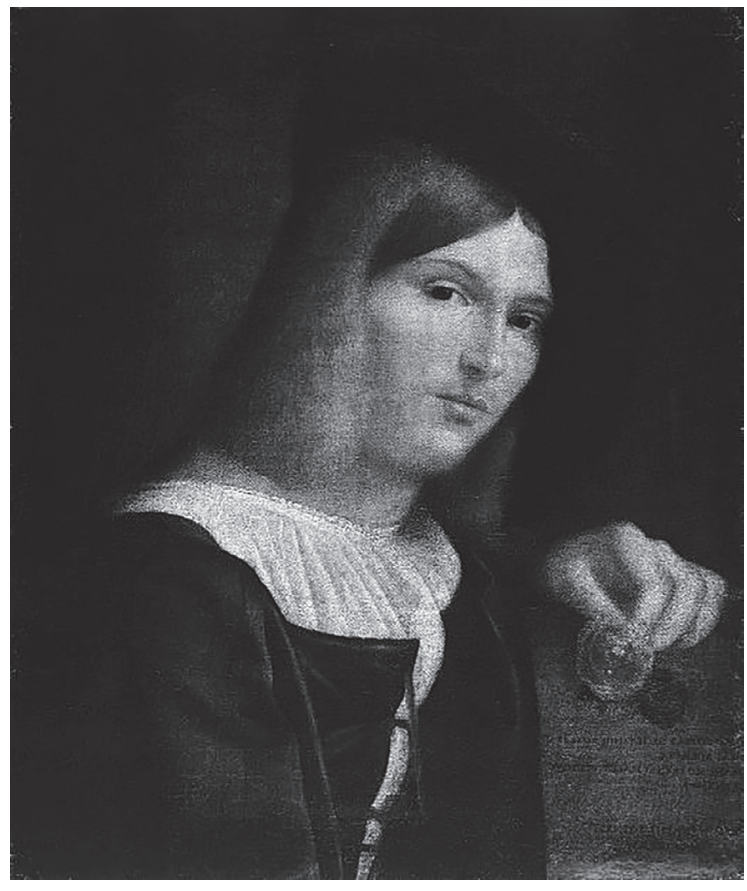

Obrázek 5: Francesco Torbido, Portrét mladíka s růží, 1516, olej na plátně, $62 \times 51,8 \mathrm{~cm}$, Alte Pinakothek, Mnichov. Převzato z: Pfisterer (pozn. 30), s. 241, Abb. 1 